Egyptian Journal of Rabbit Science, 26(2): 195-210 (2016)

\title{
PHYSIOLOGICAL, REPRODUCTIVE AND PRODUCTIVE PERFORMANCE OF FATTENED HY-PLUS RABBIT DOES AS AFFECTED BY FEED RESTRICTCTION REGIMES
}

\author{
Safaa A. Barakat ${ }^{1}$; Mervat N. Ghazal ${ }^{1}$; Rowida M. Riad ${ }^{2}$ and T.S.T. \\ Seleem ${ }^{1}$ \\ I- Animal Production Research Institute, Agricultural Research Center, Giza, Egypt. \\ 2 - Animal Reproduction Research Institute, Agricultural Research Center, Giza, Egypt. \\ Corresponding authors: safaa_ataya@yahoo.com
}

The present work was aimed to study the reproductive capability of fattened Hy-Plus rabbit does as influenced by feed restriction regimes. Eighty seven fattened mature Hy-plus multiparous rabbit does (aged 14 months and weighed $4681 \pm 72 \mathrm{~g}$ ) were used.

The rabbit does were divided into three experimental homogeneous comparable groups (29 does each). The first group (control) was fed $150 \mathrm{~g} /$ doe daily a commercial diet. While the $2^{\text {nd }}$ and the $3^{\text {rd }}$ groups (treated groups) were fed the same diets but does in the light restriction regime (LR) were fed $120 \mathrm{~g}$ diet/ doe/ day for up 14 days and those in strong restriction regime (SR) were fed $100 \mathrm{~g}$ diet/ doel day for up 3 days before their inseminated artificially, respectively. All does within all groups were fed $170 \mathrm{~g}$ diet/ doe daily, after insemination.

Results obtained showed that, body weights of fattened Hy-Plus rabbit does at insemination, at dayl0 of pregnancy and at weaning day were significantly $(P \leq 0.05)$ affected by feed restriction regime means. Weights were arranged $(P \leq 0.05)$ descendingly as recorded by rabbit does in control, SR then LR group, respectively. While weights at day 20 of pregnancy and on delivery day were insignificantly high and in descending order of does, control; SR then LR, respectively. Blood picture and total protein and its fractions and some enzymes indicated that liver and kidney functions of fattened mature Hy-plus rabbit does significantly $(P \leq 0.05)$ affected by feed restriction regime. Such parameters were better $(P \leq 0.05)$ descendingly being $S R$ and $L R$ regime, than control group, respectively. Sexual hormones concentration and leptin hormone levels in blood were significantly $(P \leq 0.05)$ high, while leptin hormone concentrations in milk were nonsignificantly low in $S R$ regime and LR regime, than control group, 
respectively. Fertility trait was affected $(P \leq 0.05)$ by feed restriction regime. Each of conception; kindling and abortion rates and litter size and weight at birth and at weaning were significantly $(P \leq 0.05)$ high due to $S R$ regime followed by LR regime, then control group. Bunny weight at birth and at weaning didn't affected significantly by feed restriction regime, while rabbit does exposed to $L R$ regime recorded pre-weaning mortality rates significantly $(P \leq 0.05)$ higher than those of $S R$ regime, then control group. Milk yield and milk lactose of fattened Hy-Plus rabbit does were high $(P \leq 0.05)$ due to SR regime, then LR regime and control group. While percentages of milk protein; fat and ash didn't affected significantly by feed restriction regime

Conclusively, it could be concluded that, there was strong relationship between low fertility of rabbit does and their fattening. Deleteriously effects of fattening on rabbit does reproductivity could be alleviated by using feed restriction regime.

Key words: Rabbit; doe; feed restriction; fertility; blood

Nutritional disorders are known to reduce reproductive and productive performance (Rommers et al., 2004a and Brecchia et al., 2006). Diets with adequate energy contents can induce both an excessive fatness and malnutrition of the does with subsequent reduction of the number and growth of newborns (Fortun-Lamothe and Lebas, 2006 and Matsuoka et al., 2006). Overfeeding during rearing period has related with low reproductive performance in dairy heifers (Sejrsen et al., 1982), pullets (Whitehead, 1988) and gilts (Klindt et al., 1999). Young rabbit females fed ad libitum until first parturition usually suffer similar problems to those-mentioned for other species (Maertens, 1992). For this reason, in the last decade, some works assessed the possible impacts of different management and feeding plans for the rearing period on female development and reproduction: feed restriction (Rommers et al., 2004b), body weight at weaning at the first artificial insemination (Rommers et al., 2002) and the use of fibrous diets (Quevedo et al., 2005). However, some of these works have shown an antagonism between proper development and improvement of reproductive response. The earlier the introduction of the restriction programme and the low the energy supply, the high the voluntary feed intake of primiparous does with improved milk yield or reduced body reserves mobilization during first lactation (Nizza et al., 1997), but later or the low their pubertal maturation ( Rommers et al., 2004c). Leptin may act as a critical link between adipose tissue and the reproductive system, indicating whether 
adequate energy reserves are present for normal reproductive function (Moschos et al., 2002).

Therefore, the present study was designed to evaluate Physiological, reproductive and productive traits of fattened Hy-Plus rabbit does as affected by different feeding restricted. The first group (untreated ). While the $2^{\text {nd }}$ group were fed $120 \mathrm{~g} \mathrm{diet/doe/} \mathrm{day} \mathrm{for} \mathrm{14days,} \mathrm{and} \mathrm{the} 3^{\text {rd }}$ group were fed $100 \mathrm{~g}$ diet/doe/day for 3 days before insemenated artificially.

\section{MATERIALS AND METHODS}

\section{Animals and management}

The present trial was carried out in an industrial Rabbitry, located at Sakarah city, Giza province, Egypt. Whereas, the laboratory work was conducted in Animal Production Research Institute, in partnership with Animal Reproduction Research Institute, Agriculture Research Center, Giza, Egypt.

A total number of 87 fattened Hy-Plus multiparous rabbit does aged 14 months and $4681 \pm 72 \mathrm{~g}$ average body weight were used in the present work. All the experimental rabbit does were healthy and clinically free from the internal and external parasites and were kept under the same managerial and hygienic conditions according to the Rabbitry routine work. The rabbit does were divided into three experimental homogeneous comparable groups (29 does /group). Rabbits within the first group were fed $150 \mathrm{~g} /$ doe daily a commercial diet according to NRC (1977) recommendations and they were kept untreated as a control group. While rabbits in the $2^{\text {nd }}$ and $3^{\text {rd }}$ groups (treated groups) were fed the same basal diet and exposed to two different feed restriction regimes before their insemination artificially. Does in the $2^{\text {nd }}$ group were fed $120 \mathrm{~g}$ basal diet/ day/doe for 14 days continuously as a light restriction regime (LR). Whereas, those in the $3^{\text {rd }}$ group were fed only $100 \mathrm{~g}$ basal diet/day/doe for 3days as a strong restriction regime (SR). After insemination, all does were fed the same basal diet at a rate of $170 \mathrm{~g} /$ day/ doe.

The ingredients and chemical composition of the basal pelleted ration fed to rabbits, during the whole experimental period are shown in Table 1.

\section{Fertility traits}

Does were weighed individually at the beginning of the experiment; at insemination day, at the $10^{\text {th }}$ and the $20^{\text {th }}$ day of pregnancy, as well as, at delivery and weaning days.

Palpation of all rabbit does was carried out on day 12 post insemination to determine pregnancy. At kindling,values abortion; conception and kindling 
Table 1. The ingredients and chemical composition of the pellet ration fed to rabbits, during the experimental period.

\begin{tabular}{|l|l|l|c|}
\hline Ingredients & $(\%)$ & \multicolumn{2}{|l|}{ Vitamins and } \\
premix per Kilogram.
\end{tabular}

** Calculated according to NRC (1977) for rabbits.

rates and litter size and weight at birth were recorded. Pre-weaning mortality rates and milk yield per doe were estimated weekly during the suckling period. The youngs of each litter were prevented from suckling for 24 hours by separation from the doe. The bunnies and doe were weighed before and after suckling and the mean of increase in weight of bunnies and decrease in weight of doe were indicated as daily milk yield (Davies et al ., 1964 ). Milk samples were taken individually within each group, on the $21^{\text {st }}$ day of lactating period (peak of milk production). A part of fresh milk sample was immediately analyzed to determine milk protein, fat, lactose and ash by using Milkoscan ${ }^{\circledR}$ analyzer-130 B, N. Foss Electronic-Denmar. 


\section{Blood sampling and analyses}

Blood samples of rabbit does were collected from the marginal ear vein of the four does within each experimental group at day 15 of pregnancy. The samples were collected into dry clean centrifuge tubs, the plasma were separated by centrifugation of blood at $3000 \mathrm{rpm}$ for $15 \mathrm{~min}$, and stored in deep freezer at $-20^{\circ} \mathrm{C}$ until biochemical analysis. Non-coagulated, fresh blood was tested shortly after collection for determination of blood pictures including red blood cells count (RBCs, $10^{6} / \mathrm{mm}^{3}$ ), white blood cells count (WBCs, $10^{3}$ \% $\left.\mathrm{mm}^{3}\right)$ and hemoglobin $(\mathrm{Hb}, \mathrm{g} / \mathrm{dl})$ and hematocrite concentration according to Drew et al. (2004 ). Total protein (TP, g/ dl) and albumin (Alb, g/ dl) levels were determined using commercial kits supplied by Randox (Randox laboratories Ltd, Crumlin, Co, Antrim, UK) according to Doumas et al.(1981). Golbulin $(\mathrm{Glb}, \mathrm{g} / \mathrm{dl})$ concentration was estimated by subtracting the values of Alb from the corresponding values of TP per sample. Plasma creatinine (Crea. g/ dl) was determined by the colorimetric method with commercial kits obtained from Bochringer (Germany). plasma samples were analyzed for determinations of aspartate aminotransferase (AST, U/L), alanine transaminase (ALT, U/L), using a commercial kits (Linear Chemicals, Barcelona, Spain) according to the manufacturer procedure. All samples were run in duplicate and assayed by the same investigator, who was blind to the experimental situation.

\section{Hormonal assays}

The tested hormones Estradioll-17 ${ }_{2 \alpha}$ (E 2) and progesterone (P4)levels were quantified by RIA technique as described by Dubourdieus et al. (1994) and Benkrane (1989) and Garret (1989), respectively. All kits were purched from Immuno-Tech Company and the analysis was done according to the outlines described by the manufactures. Blood sampling for leptin were determined by double antibodyRIA using the multi-species leptin kit (Linco Research Inc., St. Charles, MO, USA) as reported by (Brecchia et al., 2008).

Blood urea nitrogen level was assayed by quantitative colorimetric method and measured by spectrophotometer at $525 \mathrm{~nm}$ (Sigma kits). Blood NH3 was determined according to Conway (1957) method.

\section{Statistical analysis}

Data were analyzed using the General Linear Model procedure of SAS Program SAS ( 2001).

$$
\mathbf{Y}_{\mathrm{ij}}=\mu+\mathbf{D}_{\mathrm{i}}+\mathbf{e}_{\mathrm{ij}}
$$

Where $Y_{i j}$ is the observation on $\mathrm{ij}^{\text {th }}$ trait, $\mu$ is the overall mean, $D_{i}$ is the effect of $i^{\text {th }}$ diet and $e_{i j}$ is the random error. Percentage values were transformed to $\operatorname{arc}-\sin$ values before being statistically analyzed. Numbers of conceived 
does and kindling rates were analyzed using the Contingency Tables according to Everitt (1977). Duncan's new multiple range tests was used to test the significance of the differences between means Duncan (1955).

\section{Body weights}

\section{RESULTS AND DISCUSSION}

Data presented in Table 2 showed that, body weights (BW) of fattened rabbit does at insemination day; on day 10 of pregnancy and weaning day were significantly $(\mathrm{P} \leq 0.05)$ affected by feed restriction and regime means. Weights were arranged $(\mathrm{P} \leq 0.05)$ in descending order as recorded by rabbit does in control, SR then LR, group, respectively. While, weights of rabbit does on day 20 of pregnancy and on delivery day were insignificantly high and in being descending order as recorded by does in control; SR then LR, respectively.

\section{Fertility traits}

Data in Table 3 indicated that, fertility traits of fattened Hy-plus rabbit does, inseminated artificially were significantly $(\mathrm{P} \leq 0.05)$ affected by feed restriction regime. Each of conception; kindling and abortion rates and litter size and weight at birth $\&$ at weaning were significantly $(\mathrm{P} \leq 0.05)$ higher due to SR regime followed by LR system, than control group. Bunny weight at birth and at weaning didn't affected significantly by feed restriction regime, while fattened Hy-Plus rabbit does exposed to LR system recorded pre-weaning mortality rates significantly $(\mathrm{P} \leq 0.05)$ higher than those of $\mathrm{SR}$ regime and then control group. This may be due to increase litter size in LR and SR regime than control and this is in normal range.

\section{Milk yield and composition}

Data in Tables 4 and 5 revealed that, milk yield and lactose of fattened Hy-Plus rabbit does the were highly significant $(\mathrm{P} \leq 0.05)$ during $\mathrm{SR}$ regime, followed by LR regime, and then control group, respectively, while percentages of milk protein; fat and ash didn't significantly affected by feed restriction regime.

\section{Blood constitutes}

Data presented in Table 6 stated that, blood picture represented in RBCs ,WBCs, $\mathrm{Hg}$ and $\mathrm{Ht}$, serum total protein and its fractions (albumin; globulin and A/G ratio); some enzymes indicated liver function (AST and ALT) and kidney function (blood NH3 and blood urea) were of fattened mature Hy-plus rabbit does significantly $(\mathrm{P} \leq 0.05)$ affected by feed restriction regime. 
Table 2. Weight of fattened mature Hy-plus rabbit does, during different physiological status as affected by feed restriction regime (Means \pm SE).

\begin{tabular}{|l|l|l|l|}
\hline \multirow{2}{*}{ Doe weight } & \multirow{2}{*}{ Control } & \multicolumn{2}{|c|}{ Feed restricted groups } \\
\cline { 3 - 4 } & & \multicolumn{1}{|c|}{ LR } & SR \\
\hline Initial weight & $4697.3 \pm 104.2$ & $4668.4 \pm 112.6$ & $4681.9 \pm 127.2$ \\
\hline at insemination day & $4742.6 \pm 97.3^{\mathrm{a}}$ & $4496.7 \pm 124.6^{\mathrm{b}}$ & $4604.8 \pm 109.3^{\mathrm{ab}}$ \\
\hline On day $10^{\text {th }}$ of pregnancy $^{\mathrm{a}}$ & $4785.3 \pm 102.6^{\mathrm{a}}$ & $4560.0 \pm 113.7^{\mathrm{b}}$ & $4664.8 \pm 118.2^{\mathrm{ab}}$ \\
\hline On day $20^{\text {th }}$ of pregnancy $^{\mathrm{b}}$ & $4840.2 \pm 108.3$ & $4653.8 \pm 99.2$ & $4751.9 \pm 127.3$ \\
\hline On delivery day & $4987.3 \pm 106.6$ & $4802.6 \pm 127.2$ & $4892.7 \pm 116.7$ \\
\hline At weaning day & $4771.2 \pm 103.5^{\mathrm{a}}$ & $4507.6 \pm 113.3^{\mathrm{b}}$ & $4531.3 \pm 129.6^{\mathrm{ab}}$ \\
\hline
\end{tabular}

Means within the same row bearing different letter superscripts $(\mathrm{a}, \mathrm{b})$ are significantly $(\mathrm{P} \leq 0.05)$ different.

Table 3. Fertility traits of fattened mature Hy-plus rabbit does, inseminated artificially as affected by feed restriction regime (Means \pm SE).

\begin{tabular}{|l|c|c|c|}
\hline \multirow{2}{*}{ Variable } & \multirow{2}{*}{ Control } & \multicolumn{2}{c|}{ Feed restricted groups } \\
\cline { 3 - 4 } & & LR & SR \\
\hline Number of inseminated does & 29 & 29 & 29 \\
\hline Number of conceived does & $10^{\mathrm{c}}$ & $16^{\mathrm{b}}$ & $20^{\mathrm{a}}$ \\
\hline Conception rate $(\%)$ & $34.5^{\mathrm{c}}$ & $55.2^{\mathrm{b}}$ & $68.9^{\mathrm{a}}$ \\
\hline Number of kindled does & $10^{\mathrm{c}}$ & $15^{\mathrm{b}}$ & $19^{\mathrm{a}}$ \\
\hline Abortion rate (\%) & $0.00^{\mathrm{c}}$ & $6.22^{\mathrm{b}}$ & $5.00^{\mathrm{a}}$ \\
\hline Kindling rate (\%) & $34.5^{\mathrm{c}}$ & $51.75^{\mathrm{b}}$ & $65.52^{\mathrm{a}}$ \\
\hline Litter size at birth & $4.93 \pm 0.49^{\mathrm{b}}$ & $6.87 \pm 0.63^{\mathrm{a}}$ & $6.93 \pm 0.60^{\mathrm{a}}$ \\
\hline Bunny weight at birth (gm) & $47.53 \pm 3.42$ & $44.89 \pm 3.09$ & $44.95 \pm 4.12$ \\
\hline Litter weight at birth $(\mathrm{gm})$ & $234.9 \pm 29.6^{\mathrm{b}}$ & $308.7 \pm 34.2^{\mathrm{a}}$ & $311.8 \pm 32.8^{\mathrm{a}}$ \\
\hline Litter size at weaning & $4.84 \pm 0.42^{\mathrm{b}}$ & $6.04 \pm 0.48^{\mathrm{a}}$ & $6.11 \pm 0.49^{\mathrm{a}}$ \\
\hline Pre-weaning mortality rate & $1.83 \pm 0.11^{\mathrm{b}}$ & $12.08 \pm 2.03^{\mathrm{a}}$ & $11.83 \pm 1.52^{\mathrm{a}}$ \\
\hline Bunny weight at weaning (gm) & $862.9 \pm 37.4$ & $814.3 \pm 33.8$ & $803.7 \pm 34.8$ \\
\hline Litter weight at weaning (gm) & $4178.7 \pm 29.6^{\mathrm{b}}$ & $4916.5 \pm 34.2^{\mathrm{a}}$ & $4912.2 \pm 32.8^{\mathrm{a}}$ \\
\hline
\end{tabular}

Means within the same row bearing different letter superscripts $(a, b)$ are significantly $(\mathrm{P} \leq 0.05)$ different. 
Table 4. Milk yield (g/ doe) of fattened mature Hy-plus rabbit does, inseminated artificially as affected by feed restriction regime (Means \pm SE).

\begin{tabular}{|c|c|c|c|c|}
\hline \multicolumn{2}{|c|}{ Nursing period } & \multirow{2}{*}{ Control } & \multicolumn{2}{|c|}{ Feed restricted groups } \\
\cline { 1 - 2 } From & Till & & LR & SR \\
\hline Birth & 7 days & $584.3 \pm 41.2^{\mathrm{b}}$ & $692.7 \pm 57.3^{\mathrm{a}}$ & $721.4 \pm 61.8^{\mathrm{a}}$ \\
\hline Birth & 14 days & $1232.6 \pm 87.3^{\mathrm{b}}$ & $1518.9 \pm 92.6^{\mathrm{a}}$ & $1561.3 \pm 97.5^{\mathrm{a}}$ \\
\hline Birth & 21 days & $2134.6 \pm 111.2^{\mathrm{b}}$ & $2501.3 \pm 129.3^{\mathrm{a}}$ & $2618.9 \pm 130.2^{\mathrm{a}}$ \\
\hline Birth & 28 days & $2962.4 \pm 132.9^{\mathrm{b}}$ & $3403.4 \pm 134.6^{\mathrm{a}}$ & $3589.2 \pm 151.2^{\mathrm{a}}$ \\
\hline Birth & 35 days & $3351.3 \pm 161.9^{\mathrm{b}}$ & $3859.4 \pm 157.3^{\mathrm{a}}$ & $3972.8 \pm 169.5^{\mathrm{a}}$ \\
\hline
\end{tabular}

Means within the same row bearing different letter superscripts $(a, b)$ are significantly $(\mathrm{P} \leq 0.05)$ different.

Table 5. Milk composition of fattened mature Hy-plus rabbit does, as affected by feed restriction regime (Means \pm SE).

\begin{tabular}{|l|c|c|c|}
\hline \multirow{2}{*}{ Milk composition(\%) } & \multirow{2}{*}{ Control } & \multicolumn{2}{c|}{ Feed restricted groups } \\
\cline { 3 - 4 } & & LR & SR \\
\hline Milk protein & $11.79 \pm 0.48$ & $11.51 \pm 0.57$ & $11.86 \pm 0.43$ \\
\hline Milk fat & $17.92 \pm 0.31$ & $18.12 \pm 0.52$ & $17.89 \pm 0.46$ \\
\hline Milk lactose & $3.66 \pm 0.17^{\mathrm{b}}$ & $3.91 \pm 0.33^{\mathrm{ab}}$ & $4.18 \pm 0.22^{\mathrm{a}}$ \\
\hline Milk ash & $4.52 \pm 0.33$ & $4.59 \pm 0.26$ & $4.71 \pm 0.31$ \\
\hline
\end{tabular}

Means within the same row bearing different letter superscripts $(a, b, c)$ are significantly $(\mathrm{P} \leq 0.05)$ different.

Table 6. Blood picture and some blood serum constitute of fattened mature Hyplus rabbit does as affected by feed restriction regime (Means \pm SE).

\begin{tabular}{|l|l|l|l|}
\hline \multirow{2}{*}{ Variable } & \multirow{2}{*}{ Control } & \multicolumn{2}{c|}{ Feed restricted groups } \\
\cline { 3 - 4 } & & \multicolumn{1}{c|}{ LR } & SR \\
\hline Red blood cells $\left(\mathrm{N} \mathrm{x} \mathrm{10} / \mathrm{mm}^{3}\right)$ & $5.47 \pm 0.29^{\mathrm{b}}$ & $6.33 \pm 0.37^{\mathrm{a}}$ & $6.74 \pm 0.35^{\mathrm{a}}$ \\
\hline White blood cells $\left(\mathrm{N} \mathrm{x} 10^{3} / \mathrm{mm}^{3}\right)$ & $6.97 \pm 0.33^{\mathrm{b}}$ & $7.59 \pm 0.40^{\mathrm{ab}}$ & $7.78 \pm 0.40^{\mathrm{a}}$ \\
\hline Hemoglobin $(\mathrm{gm} / \mathrm{dL})$ & $10.38 \pm 0.47^{\mathrm{b}}$ & $11.89 \pm 0.39^{\mathrm{a}}$ & $12.09 \pm 0.44^{\mathrm{a}}$ \\
\hline Hematocrite $(\%)$ & $32.87 \pm 1.19^{\mathrm{b}}$ & $35.07 \pm 1.42^{\mathrm{ab}}$ & $36.31 \pm 1.59^{\mathrm{a}}$ \\
\hline Total protein $(\mathrm{m} \mathrm{gm} / 100 \mathrm{ml})$ & $6.37 \pm 0.17^{\mathrm{c}}$ & $7.46 \pm 0.14^{\mathrm{b}}$ & $7.88 \pm 0.22^{\mathrm{a}}$ \\
\hline Albumin $(\mathrm{mgm} / 100 \mathrm{ml})$ & $3.07 \pm 0.07^{\mathrm{c}}$ & $3.73 \pm 0.08^{\mathrm{b}}$ & $3.99 \pm 0.08^{\mathrm{a}}$ \\
\hline Globulin $(\mathrm{m} \mathrm{gm} / 100 \mathrm{ml})$ & $3.30 \pm 0.04^{\mathrm{c}}$ & $3.73 \pm 0.02^{\mathrm{b}}$ & $3.89 \pm 0.03^{\mathrm{a}}$ \\
\hline A/ G ratio & $0.930 \pm 0.01^{\mathrm{b}}$ & $1.00 \pm 0.01^{\mathrm{ab}}$ & $1.026 \pm 0.02^{\mathrm{a}}$ \\
\hline AST $(\mathrm{U} / \mathrm{L})$ & $22.46 \pm 1.24^{\mathrm{b}}$ & $27.83 \pm 1.97^{\mathrm{ab}}$ & $28.92 \pm 1.44^{\mathrm{a}}$ \\
\hline ALT $(\mathrm{U} / \mathrm{L})$ & $14.04 \pm 0.78^{\mathrm{b}}$ & $16.89 \pm 0.74^{\mathrm{ab}}$ & $16.96 \pm 0.93^{\mathrm{a}}$ \\
\hline Blood NH3 $(\mu \mathrm{g} / \mathrm{ml})$ & $5.17 \pm 0.18^{\mathrm{a}}$ & $4.52 \pm 0.29^{\mathrm{b}}$ & $4.23 \pm 0.11^{\mathrm{b}}$ \\
\hline Blood Urea N $(\mathrm{mg} / \mathrm{dl})$ & $14.45 \pm 1.14^{\mathrm{a}}$ & $11.82 \pm 0.82^{\mathrm{b}}$ & $10.91 \pm 0.66^{\mathrm{b}}$ \\
\hline
\end{tabular}

Means within the same row bearing different letter superscripts $(a, b, c)$ are significantly $(\mathrm{P} \leq 0.05)$ different 
Such parameters were significantly $(\mathrm{P} \leq 0.05)$ better descendingly due to $\mathrm{SR}$ regime, LR system, and then control group, respectively.

\section{Hormonal profiles}

Sexual hormones concentration in E2 and P4 and leptin hormone levels in blood were significantly $(\mathrm{P} \leq 0.05)$ high, while leptin hormone concentrations in milk were non-significantly low as recorded by fattened Hy-plus rabbit does in SR regime and LR system, then control group, respectively, (Table 7 ).

Heavy breeds in all species have low fetility in males and females and produce few offspring. The rabbit does which used in this experiment were suffering from over weight which was higher than the normal weight by (600$700 \mathrm{~g}$ ) for this breed and at that age. This over weight caused a negative effect on reproductive performance of these does as shown in Table 2 .

To solve the over weight problem and bad productive performance in this herd we used two feeding plane, where the rabbit does were subjected to feed restriction before AI, light and strong regime. The feed offered were reduced from 150 to 120 or $100 \mathrm{gm}$ in (light and strong) regime, respectively.

The data in Table 3 showed that there was a problem in ovulation and pregnancy, where the does were suffer from low pregnancy rate, it was 34 $\%$ in control group and the treated groups recorded $(55.2 \%$ and $68.9 \%)$ in LR and SR, respectively and this improvement in pregnancy rate in treated groups were due to feed restriction regime before insemination. The purpose of this feeding plan was to prevent the excessive fat deposition that already found in does under study. The effect of feed restriction regime on the regulatory mechanisms of metabolism during reducation and compensatory growth has been investigated in several animal species (Rhind et al., 2000). Although, the basic underlying physiological responses to underfeeding might be common to all mammals. Improving fertility rate by fasting was reported by Eiben et al., (2010) who noticed a better fertility rate generally in the treated group $(\mathrm{P}<0.10)$ and can be explained by the older breeding age and by the favorable influence of flushing on ovulation and kindling rate was the highest over the whole experimental period.

Also Table 4 and 5 showed that litter size at birth increased significantly $(\mathrm{P} \leq 0.05)$ in treated groups and recorded $40 \%$ more than control group. While,the bunny weight at birth in treated groups not affected significantly and the difference was less than $2.5 \mathrm{~g}$, this difference continues to weaning. Although the does under feed restriction but the milk production increased significantly about 500-600 g compared to control 
Table 7. Sexual hormones concentration and leptin hormone level of fattened mature Hy-plus rabbit does, as affected by feed restriction regime (Means \pm SE).

\begin{tabular}{|l|l|l|l|}
\hline \multirow{2}{*}{ Hormones concentration } & \multirow{2}{*}{ Control } & \multicolumn{2}{|c|}{ Feed restricted groups } \\
\cline { 3 - 4 } & & \multicolumn{1}{|c|}{ LR } & \multicolumn{1}{c|}{ SR } \\
\hline Estradiol $17_{2 \alpha}(\mathrm{pg} / \mathrm{ml})$ & $25.31 \pm 1.15^{\mathrm{b}}$ & $28.57 \pm 1.43^{\mathrm{a}}$ & $28.82 \pm 1.44^{\mathrm{a}}$ \\
\hline Progesterone $(\mathrm{pg} / \mathrm{ml})$ & $0.717 \pm 0.012^{\mathrm{b}}$ & $0.794 \pm 0.022^{\mathrm{a}}$ & $0.798 \pm 0.023^{\mathrm{a}}$ \\
\hline Leptin in blood serum $(\mathrm{ng} / \mathrm{dl})$ & $4.21 \pm 0.40^{\mathrm{c}}$ & $5.01 \pm 0.36^{\mathrm{b}}$ & $5.91 \pm 0.44^{\mathrm{a}}$ \\
\hline Leptin in milk $(\mathrm{ng} / \mathrm{dl})$ & $3.42 \pm 0.31$ & $3.29 \pm 0.24$ & $3.24 \pm 0.29$ \\
\hline
\end{tabular}

Means within the same row bearing different letter superscripts $(a, b, c)$ are significantly $(\mathrm{P} \leq 0.05)$ different.

group. This may be due to increased litter size at birth in groups of regime (LR-SR). The content of fat and protein didn't affected and were almost equal in all groups. Does will secrete more milk if litter size at birth is large (EL-Maghawry et al., 1993). This increase in milk production, is however, not entirely proportional to the needs of more suckling. There were a negative correlation between litter size and individual bunny weight Therefore, one kit consumes less milk and so the individual weight will be low (Petersen et al., 1996). When both litter size and individual weight of suckling rabbits increase this could be only due to the high milk production of the doe. This could be explained our result in increasing the total litter weight and decrease individual weight at birth and weaning and increase milk production in SR then LR than control. This is in agreement with Eiben et al. (2010)

It is known that, there is an inverse relationship between fatting and productive performance where there were an improvement in sexual hormones (estrogen and progesterone ) in treated groups as a resulte of feed restriction compared to control group. Also, this improvement reflect on blood picture and other parameters which greatly improved compared to control groups. Leptin is produced by adipose tissue and its blood levels are correlated with body reserves and the availability of nutrients (Ahima and Flier, 2000). Moreover, it is involved in the regulation of body weight either suppressing appetite or increasing metabolic rate (Friedman and Halaas, 1998). Leptin produced and secreted by adipose cells is an important in the long-term regulation of body weight and body fat mass content. The gradual increase of the circulating leptin in rabbits may reflect improvement of sexual hormones and fertility (Barb et al., 2001a) as shown in Tables 6 and 7. 
Ther present results on leptin concentrations of blood serum during feed restriction are in agreement with partially comparable with those of Chilliard et al. (2000) and Barb et al. (2001b). All sexual hormone here are more related to the feed restriction program and it was in agreement with other studies in heifers (Hornick et al., 1998); and in sows (Quesnel et al., 1998) .

A doe rabbits within all groups were fed $170 \mathrm{~g}$ diet/ doe daily, after insemination, during the stages of pregnancy where the energy requirements for the fetal growth are modest and the energy balance of the does is positive (Parigi-Bini et al., 1990).

The rabbit does subjected to feed restriction before artificial insemination lead to an improvement in blood pictures and some blood serum constitutents ; liver and kidney functions; sexual and lipten hormones; fertility traits and milk yield and composition. This finding is in agreement with Hornick et al. (2000); Dal Bosco et al. (2003); Rommers et al. (2004b) and Cardinali et al. (2008).

Hy-Plus breed was imported from the outside, so we have to use it with the most profitable way by using it more than one productive year, subsequentaly reduce the cost of productivity and save currency.

Conclusively, it could be concluded that, fattened rabbit does characterized by low reproductive performance. Such problem could be solved by restricting feed. Using strong restriction regime (SR) within short period gave better in sexual hormons concentration and leptin levels in blood, also (SR) improving significant fertility and conception, kindiling rates, and recorded high increased in litter size and weight at birth and weaning. Milk yield and lactose of rabbit does were high than that of light restriction regime (LS)

\section{REFERENCES}

Ahima, R.S.: Flier, J. S. (2000). Leptin. Annu Rev Physiol., 62:413-37.

Barb, C. R.; Kraeling, R. R. and Rampacek, G. B. (2001a). Nutritional regulators of the hypothalamic-pituitary axis in pigs. J. Reprod. Fert. (Suppl) , 58: 1-15.

Barb, C. R.; Barrett, J. B.; Kraeling, R. R. and Rampacek, G. B. (2001b). Serum leptin concentrations, luteinizing hormone and growth hormone secretion during feed and metabolic fuel restriction in prepuberal gilts. Domest. Anim. Endocrinol., 20: 47-63.

Benkrane, M. (1989). Production of monoclonal antibodies complementary to an antibody-antigen complex. J. Immunol. Methods, 111-189. 
Brecchia, G.; Cardinali, R.; Dal Bosco, A.; Boiti, C.; Castellini, C. (2008). Effect of a reproductive rhythm based on rabbit doe body condition on fertility and hormones. 9th World Rabbit Cong. Verona - Italy, June 10-13, pp. 309-313.

Brecchia, G.; Bonanno, A.; Galeati, G.; Federici, C.; Maranesi, M.; Gobbetti, A.; Gerani, M. and Boiti, C. (2006). Hormonal and metabolic adaptation to fasting: effects on the hypothalamic-pituitary-ovarian axis and reproductive performance of rabbit does. Domest. Anim. Endocrinol., 31: 105-122.

Cardinali, R.; Dal Bosco, A.; Bonanno, A.; Di Grigoli, A.; Rebollar, P.G.; Lorenzo, P.L. and Castellini, C. (2008). Connection between body condition score, chemical characteristics of body and reproductive traits of rabbit does. Livest. Sci., 116: 209-215.

Chilliard, Y.; Ferlay, A.; Faulconnier, Y.; Bonnet, M.; Rouel, J. and Bocquier, F. (2000). Adipose tissue metabolism and its role in adaptations to undernutrition in ruminants. Proceedings of the Nutrition Society, 59: 127-134.

Conway, E.J. (1957). Micro-Diffusion Analysis and Volumetric Error. $4^{\text {th }}$ edition Grosyb Cockowood and Son Lts., London, UK.

Dal Bosco, A.; Castellini, C. and Cardinali, R. (2003). Evaluation of body condition score in pregnant rabbit does by ultrasound scanner. Proc. 15th Cong. Naz. ASPA, Parma, Italy.pp 480-482.

Davis, J. S.; Widdows, E. M. and Maccance, R. A. (1964). The intake of milk and the retention of its constituents with newborn rabbits doubles its weight. Br. J. Nutr., 18: 385-392.

Doumas, B.T.; Bayso, D. D.; Carter, R. J.; Peters, T. and Schaffer, R.(1981). Determination of total serum protein. Clin. Chem., 27: 1642-1643.

Drew, P.; Harles, C.R.J.S.; Trevor, B. and John, L. (2004). Oxford Handbook of Clinical Haematology. $2^{\text {th }}$ Ed. Oxford University Press, USA.

Dubourdieu, S.; Charbonnel , B.; D`Acremont, M. F.; Carreau, S.; Spitz, I. and Bouchard, P. (1994). Effect of (GnRH) antagonist (Na1-GLU) during the periovulatory period: the luteinizing hormone surge requires secretion of GnRH. J. Clin. Endocrinol. Metabol.,78(2) : 343.

Duncan, D.B.(1955). Multiple Range and Multiple (F-test). Biometrics, 11: 1-42.

Eiben, C. S.; Kustos, K.; Kenessy, A.; Virag, G.Y. and Szendro, Z. S. (2010). Effect of different feed restriction during on production performance in rabbit does . World Rabbit Sci. , 9(1):9-14. 
EL-Maghawry, A.; Soliman, A. M. and Khalil, H. H.(1993). Doe milk production as affected by some genetic and environmental factors in New Zealand White and Californian rabbits under the Egyptian conditions. Egypt. J. Rabbit Sci., 3 (2): 141-150.

Everitt, B.S. (1977). The Analysis of Contingency Tables. Monographs of Applied Probability and Statistics. Chopman Hall, London. pp 38-66.

Fortun-Lamothe, L. and Lebas. (2006). Energy balance and reproductive performance in rabbit does. Anim. Reprod. Sci., 93, 1-15.

Friedman, J. M; Halaas, J. L. (1998). Leptin and the regulation of body weight in mammals. Nature., 395: 763-70.

Garrett, P. E. (1989). The Enigma of standardization for LH and FSH assays. $J$. Clin. Immunoassay, 12(1):18.

Hornick, J. L.; Eenaeme, C.; van Gérard, O.; Dufrasne, I. and Istasse, L. (2000). Mechanisms of reduced and compensatory growth. Domes.Anim. Endocrinol., 19: 121-132.

Hornick, J. L.; Eenaeme, C.; van Diez, M.; Minet, V. and Istasse, L. (1998). Different periods of feed restriction before compensatory growth in Belgian Blue bulls. II. Plasma metabolites and hormones. J. Anim. Sci., 76: 260-271.

Klindt, J.; Yen, J. T. and Christenson, R. K. (1999). Effect of prepubertal feeding regimen on reproductive development of gilts. J. Anim. Sci., 77: 1968-1976.

Maertens, L. (1992). Rabbit nutrition and feeding: a review of some recent developments. J. Appl. Rabbit Res., 15: 889-913.

Matsuoka, T.; Mizoguchi, Y.; Serizawa, K.; Ishikura, T.; Mizuguchi, H. and Asano, Y. (2006). Effects of stage and degree of restricted feeding on pregnancy outcome in rabbits. J. Toxicol. Sci., 31(2):166-175.

Moschos, S.; Chan, J. L. and Mantzoros, C.S.( 2002). Leptin and reproduction: a review. Ferti. Steri., 77: 433-444.

Nizza, A.; Di Meo, C. and Esposito, L. (1997). Influence of diet used before and after the first mating on reproductive performance of rabbit does. World Rabbit Sci., 5: 107-110.

NRC (1977). Nutrient Requirements of Rabbits. 2nd Ed. National Academy of Science, Washington, DC. USA.

Parigi-Bini, R.; Xiccato, G. and Cinetto, M. (1990). Energy and protein retention and partition in rabbit does during first pregnancy. Cuni. Sci., 6: $19-29$. 
Petersen, J.; Hartman, J. and Mennicken, L. (1996). Effect of prenatal on postnatal performance of does. Proc. $6^{\text {th }}$ World Rabbit Cong. Toulouse, 2: 103-106.

Quesnel, H.; Pasquier, A.; Mounier, A. M.; Louveau, I. and Prunier, A. (1998). Influence of feed restriction in primiparous lactating sows on body condition and metabolic parameters. Reprod. Nutr. Develop., 38: 261-274.

Quevedo, F.; Cervera, C.; Blas, E.; Baselga, C.; Costa, C. and Pascual, J. J. (2005). Effect of selection for litter size and feeding programme on the performance of young rabbit females during rearing and first pregnancy. Anim. Sci., 80: 161-168.

Rhind, S. M.; McMillen, S. R.; Duff, E.; Kyle, C. E. and Wright, S. (2000). Effect of long term feed restriction on seasonal endocrine changes in Soay sheep. Physiol. Behav., 71: 343-351.

Rommers, J. M.; Meijerhof, R.; Noorhuizen, J. P.T. M. and Kemp, B. (2002). Relationships between body weight at first mating and subsequent body development, feed intake, and reproductive performance of rabbit does. J. Anim. Sci., 80(8):2036-42.

Rommers, J.M.; Boiti, C.; Brecchia, G.; Mejehof, R. and Noordhuizen, J.P.T.M. (2004a). Metabolic adaptation and hormonal regulation in young rabbit does during long-term caloric restriction and subsequent compensatory growth. Anim. Sci., 79: 255-264.

Rommers, J. M.; Meijerhof, R.; Noorhuizen, J. P. T. M. and Kemp, B. (2004c). Effect of feeding program during rearing and age at first insemination on performances during subsequent reproduction in young rabbit does. Reprod. Nutr. Develop., 44: 2036-2042.

Rommers, J. M.; Meijerhof, R.; Noordhuizen, J. P. T. M. and Kemp, B. (2004b). Effect of body weight and age at first insemination on performances during subsequent reproduction in rabbit does. Reproduction, Nutrition, Development, 15: 125-136.

SAS (2001). Statistical Analysis System. User's Guide Version 8.2, Cary NC. USA.

Sejrsen, K.; Hubert, J.T.; Tucker, H. A. and Akers, R. M. (1982). Influence of nutrition on mammary development in pre- and postpubertal heifers. $J$. Dairy Sci., 65: 793-800.

Whitehead, C. C. (1988). Selection for leanness in broilers using lipoprotein concentrations as selection criterion. In: Leanness in Domestic Birds: Genetic, Metabolic and Hormonal Aspects (Ed. Leclercq.,B and Whitehead.,CC), Butter-Worths and INRA. London,England. pp. 41-57. 


\title{
الأداء الفسيولوجى والتناسلى والإنتاجى لأمهات الأرانب

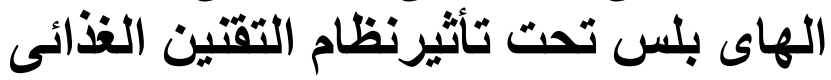

\author{
صفاء عطايا بركات'، مرفت نبيل غزال'، رويدا محمد رياض'، طارق سليمان

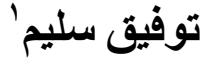

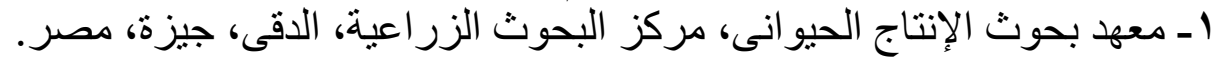

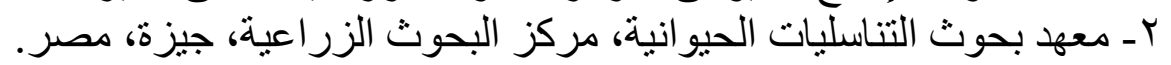

إستهدفت هذه التجربة دراسة تأثير نظام التقنين الغذائى على معدلات خصوبة

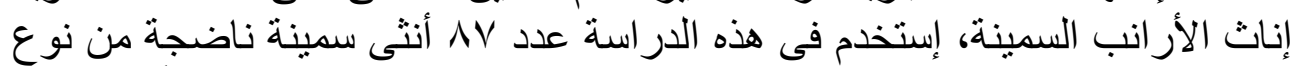

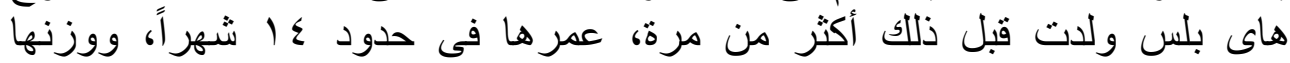

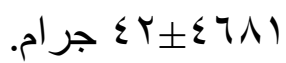

قسمت إناث الأر انب المستخدمة فى التجربة إلى ثلاثة مجموعات تجريبية

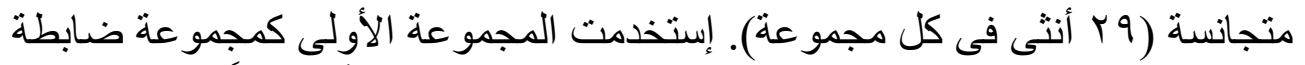

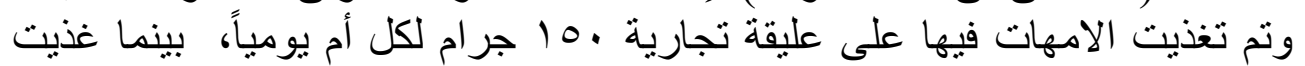

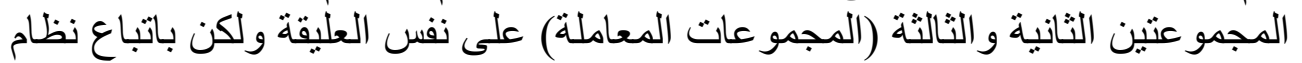

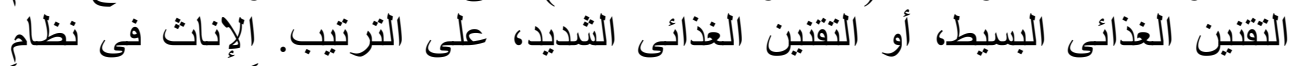

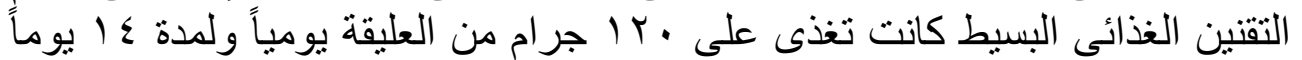

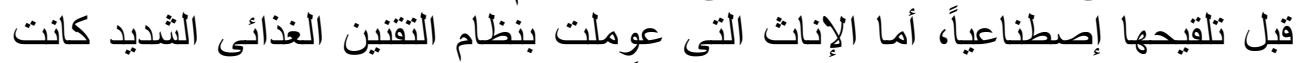

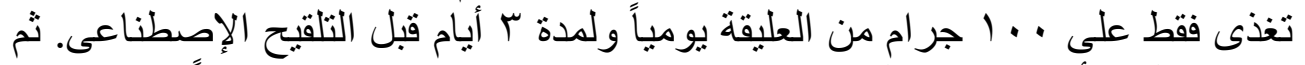

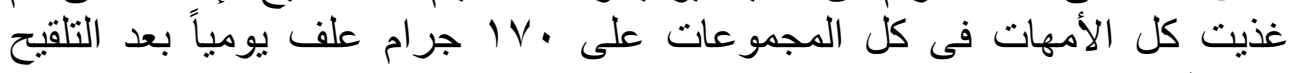

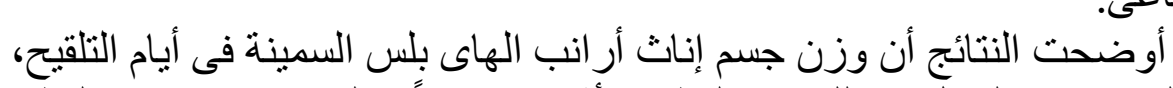

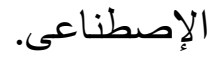

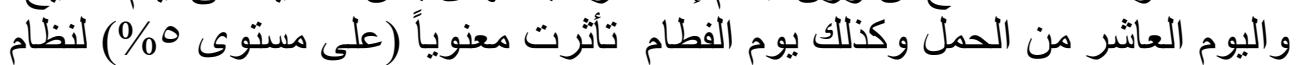

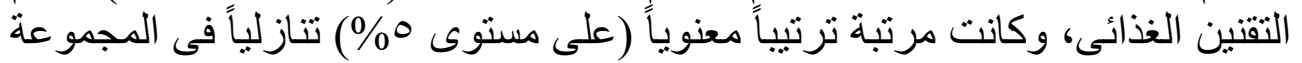

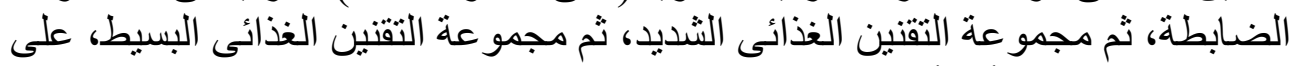

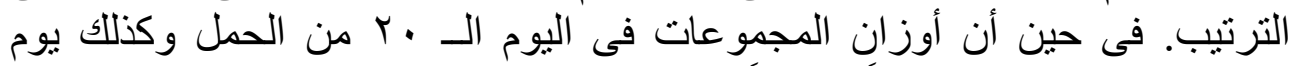

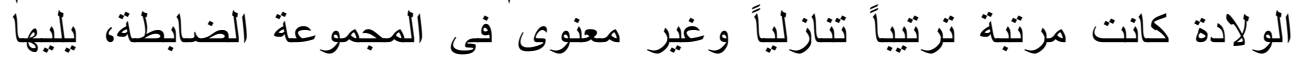

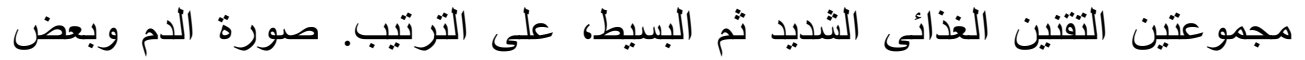

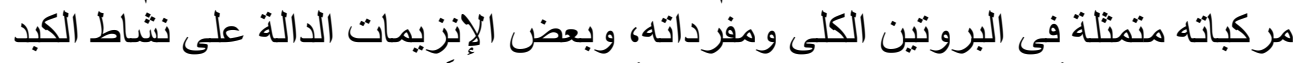

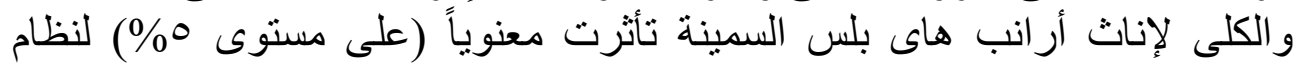

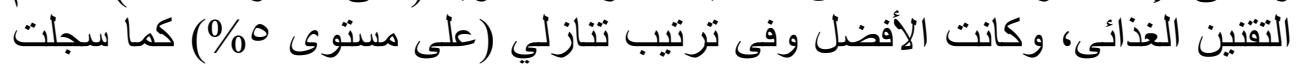




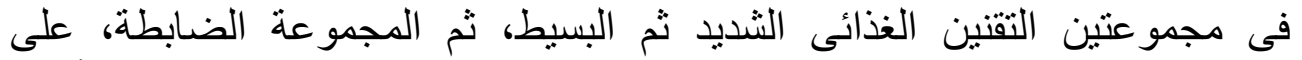

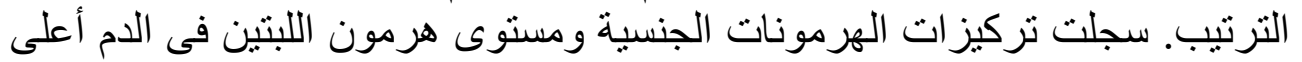

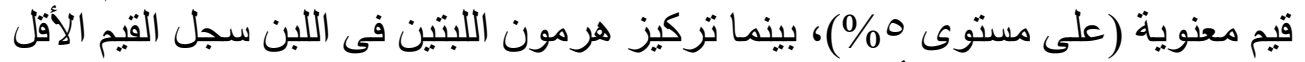

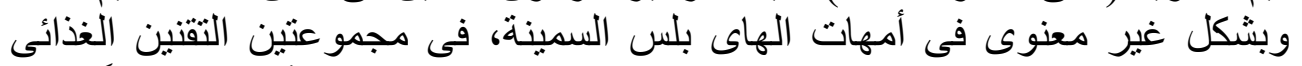

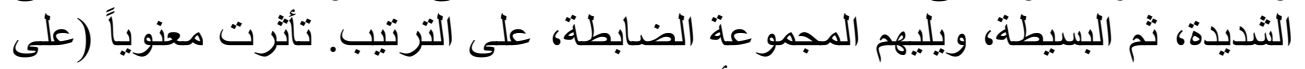

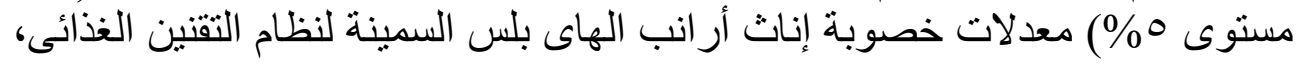

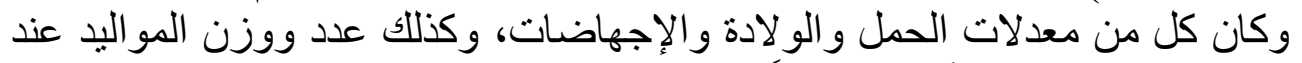

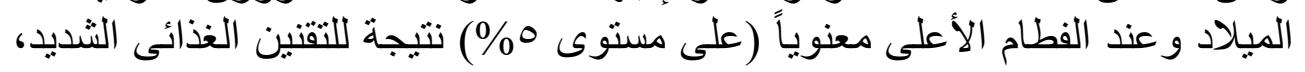

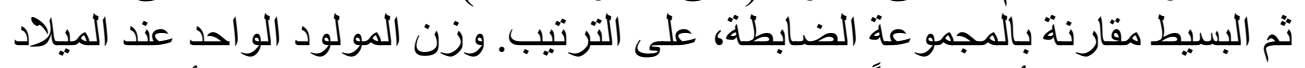

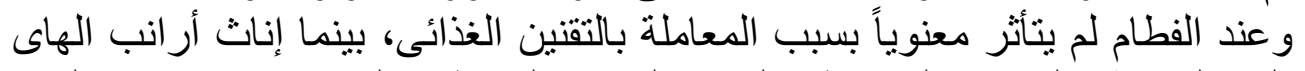

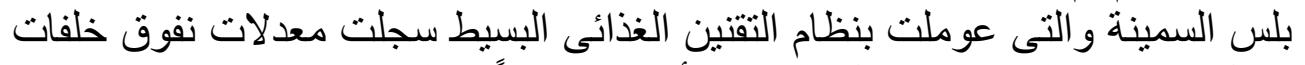

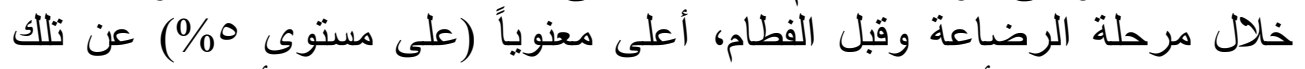

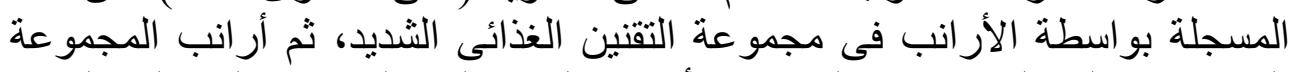

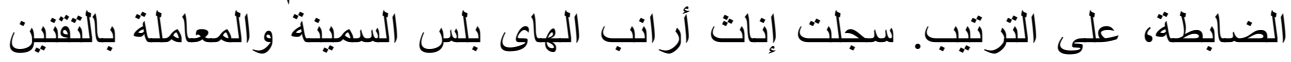

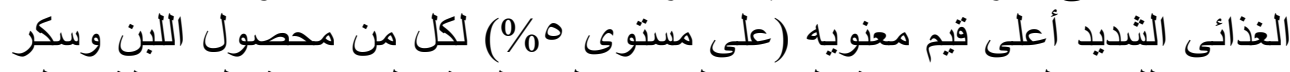

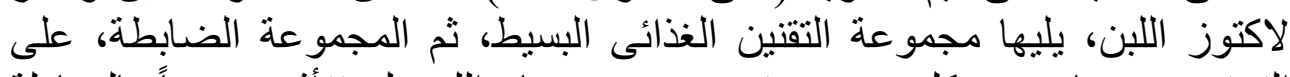

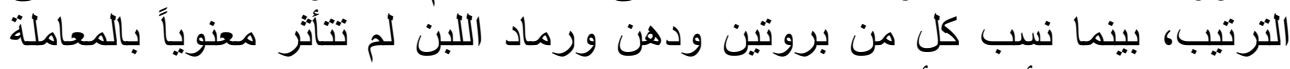
بالتقنين الغذائى لأمهات أر انب هن هاى بلس السمينة.

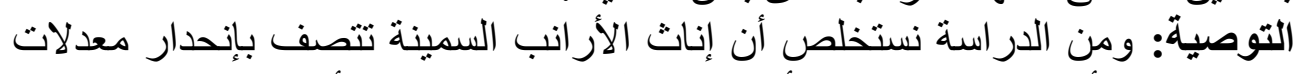

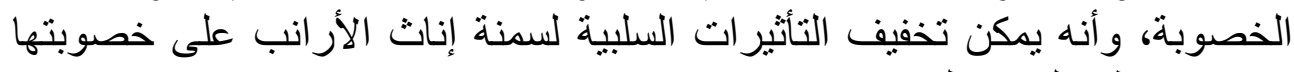

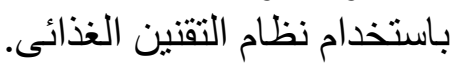

